\title{
INTERNATIONALISATION OF ADVANCED TRAINING FOR TEACHERS OF MEDICAL ENGLISH
}

\author{
Oksana Gavrilyuk $^{1}$, Irina Markovina ${ }^{2}$, Jonathan McFarland ${ }^{2}$ \\ ${ }^{1}$ Prof. V.F. Voino-Yasenetsky Krasnoyarsk State Medical University, Krasnoyarsk, Russia \\ E-Mail: oksana.gavriluyuk@mail.ru \\ ${ }^{2}$ I.M. Sechenov First Moscow State Medical University, Moscow, Russia
}

\begin{abstract}
In the present context of medical science and technology advances, growing cultural diversity and the internationalisation of higher medical education, the problem of refresher training for Medical English teachers is becoming ever more relevant. The aim of the paper is to provide a scientific basis for creation of a relevant advanced training programme for Russian university teachers of Medical English. The results of the contentanalysis of both national and international higher educational documents, a review of research, theory, and current foreign language teaching practice in Prof. V. F. VoinoYasenetsky Krasnoyarsk State Medical University (KrasSMU) and I. M. Sechenov First Moscow State Medical University (Sechenov University) allowed us to determine five principles that formed the basis for the design of a relevant advanced training programme for teachers of Medical English. Among the core principles of the programme development we suggested the principles of teacher's autonomy, professionalisation, problem-based training, innovation, and internationalisation. Within the scope of these principles, characteristics of the proposed novel approach to the organisation of professional development courses for Medical English teachers make this approach effective and relevant to the modern educational context. The proposed approach to an advanced training course design is based on the use of some novel professionally focused forms of communication between students, teachers, experts and clinicians. Our findings indicate that this approach is beneficial for modern teachers of Medical English.
\end{abstract}

Key words: higher education, internationalisation, advanced training programme, professional development, university teachers, Medical English

\section{INTRODUCTION}

The problem of teacher professional development is not a novel issue (Kennedy, 2016; Kyndt et al.2016; Opfer \& Pedder, 2011; Trust et al., 2016; Van Driel et al., 2012) since human capital is considered to be one of the key strategic resources for development of modern universities (Noorda, 2014). In the present context of medical science and technology advances, growing cultural diversity, and internationalisation of higher medical education, professional development of university teachers of medical English is becoming ever more relevant since English is considered as today's lingua franca of medical international communication (Pavel, 2014).

Submitted May $3^{\text {rd }}, 2019$, accepted for publication June $14^{\text {th }}, 2019$

() 2019 by University of Niš, Serbia | Creative Commons License: CC BY-NC-ND 
Most foreign language teachers participate in advanced training programmes on a regular basis, but most see them as being useless since they neither change teaching practice nor improve student learning (Darling-Hammond, 2000). Taking into account that languages remain a major barrier to global science (Amano et al., 2016), modern foreign language teachers need to be ready to go beyond the traditional approach to the organisation of their professional activity and work in a multidisciplinary and multicultural context, in both the university educational environment and the global educational system. They must be ready and willing to act autonomously, make important decisions, rational choices of effective methods, forms of foreign language teaching, and develop new teaching material with interactive teaching methods. These new requirements determine the necessity to discover new approaches to develop advanced training programmes for foreign language teachers. Hence, the real issue is not about providing professional training for foreign language teachers but about providing effective professional training. Specifically, within the context of higher medical education in Russia one of the biggest current challenges is to create a new type of advanced training programme for foreign language teachers that could stimulate real changes both in teaching and in student achievement.

The aim of the paper is to provide a scientific basis for creation of a novel advanced training programme for teachers of Medical English through determining its core principles, special features and possible formats. In the present paper, we generalize our previous findings on the problem of the university teacher professional development (Gavrilyuk et al., 2017; Markovina et al., 2017) and provide implications for future research drawing on the example of refresher training courses for Medical English teachers.

\section{LITERATURE REVIEW}

In the present context of medical science and technology advances, growing cultural and linguistic diversity and the internationalisation of higher education (Svensson \& Wihlborg, 2010) the problem of refresher training for Medical English teachers is becoming ever more relevant. The key question is that having been a low-priority subject in the traditional Russian educational model for so long, foreign language has now become a top priority for the effective professional development of medical specialists. Accordingly, there has been a radical change in foreign language didactics. Indeed, foreign language teaching is now seen as an essential tool for Continuous Professional Development (CPD) (Fan \& Wu, 2011).

Teaching English for medical purposes should provide diversification, a multilevel approach, and focus on both the medical professional and the student's personality, as well as correspond to actual trends in medical education. Thus, teachers should be able to handle an "interactive, three-dimensional and vivid language teaching environment" (ibid.), as well as master a wide range of study materials to teach language online, including MOOCs (massive open online courses) (Epelboin, 2015; Compton, 2015). As F. Toköz Göktepe claims, English teachers should be aware of recent teaching methods and know how to integrate them into their classrooms (Toköz Göktepe, 2015). Moreover, this new type of foreign language teaching requires that the teacher is open to a new method of creative teaching that is innovative, contextual and problem-based. Teachers must develop new ways to teach a foreign language, and of prime importance is assessing students' performance with an emphasis on the formation of a set of required competencies since this assessment is directly linked to the medical setting (Markovina et al., 2013). 
To make university teachers better prepared to the modern educational context, various professional development initiatives have been implemented in different universities. However, there is little agreement regarding the key components that should be included in an effective professional development activity (Bayar, 2014). According to the recent literature on the problem of effective professional development activities in terms of teachers' perspective (Gavrilyuk, 2015;Garanina et al., 2017; Frizen, 2016; Tomassini \& Zanazzi, 2014), effective advanced training should foster teachers' self-reflection, teachers' professional insight as their "multi-dimensional awareness" (Mann, 2005), and teachers" professional autonomy that is regarded as "the competence to develop as a self determined, socially responsible and critically aware participant in (and beyond) educational environments, within a vision of education as (inter)personal empowerment and social transformation" (Jiménez, 2007). This can be achieved through collaborative and cooperative learning, peer observation and peer review within the study groups to promote self-evaluation and peer-evaluation instead of a one-dimensional, summative evaluation of student teachers by trainers (Raths \& Lyman, 2003). Teachers' self-reflection can also be stimulated through their involvement in preparation of course reports which requires teachers' self-assessment (Shawer \& Alkahtani, 2013).

As Bayar states, any effective professional development activity should consist of the following components: 1) a match to existing teacher needs, 2) a match to existing educational institution needs, 3) teacher involvement in the design/planning of professional development activities, 4) active participation opportunities, 5) long-term engagement, and 6) high-quality instructors (Bayar, 2014). The literature analysis results also indicate that in the present context of information and communication technology advances practice-oriented e-learning environment (Yang et al., 2016) as well as professional development activities which are more regular and focused on the integration of technology into teaching rather than learning about how to use technological tools are of a special importance (Ozdemir \& Dikilitaş, 2016).

\section{MATERIALS AND METHODS}

Analysis of the literature review results allowed us to determine a set of principles that formed the basis for the design of a new type of advanced training programme developed specifically for university teachers of Medical English by Sechenov University (Irina Markovina and Jonathan McFarland) and first given in Moscow in 2015. Next year the authors decided to move from Moscow to one of the largest medical universities in Siberia, KrasSMU, as well as to invite the participants from a number of Russian universities of the region. That new programme was developed in collaboration with KrasSMU (Oksana Gavrilyuk). Different stages of the programme were implemented on the premises of Prof. V. F. Voino-Yasenetsky Krasnoyarsk State Medical University (KrasSMU) in March-April 2016, in November 2017 and in February 2018. Most of the programme participants were teachers of KrasSMU. Additionally, representatives of the medical universities of Novosibirsk, Chita, Barnaul and Omsk were engaged at the first stage of the programme (in 2016). The overall number of the programme participants (March 2016 - February 2018) was 30 .

The scientific research module of the programme was developed by members of the Educational and methodical commission in linguistic disciplines for Clinical Medicine and Pharmacy at the Coordination Council on Education "Public Health and Medical Science" of 
the Ministry of Education and Science of the Russian Federation (EMC). The decisions on what to include in this module were made based on an up-to-date language teaching literature review. Different parts of the module were concerned with modern tendencies in teaching languages for medical professionals and new ways to teach professional communication in a multidisciplinary and multicultural context, including problem-based and context-based teaching with the use of interactive teaching methods and information technology. The problems of fostering medical students' motivation to study foreign languages and foreign language teacher's professional autonomy and independent professional self-development were discussed as well. The practical part of the programme was conducted in partnership with international specialists - Jonathan McFarland, a British expert in Medical English, Dr Isabel Garau, a practicing Spanish oncologist, and Dr Gavin Francis, a Scottish physician and a writer.

The audience took an active part in programme implementation since all the participants had to work in an online setting and develop a set of practical and analytical tasks for the event both during the distance part of the course and within the periods of on-site training. The specific feature of this advanced training ESP programme for language teachers was to engage clinicians, postgraduate and undergraduate medical students. Analysis of the educational process outcomes and open discussions with participants of the developed advanced training programme (February 2017, February 2018) have also become an important source of information.

During different stages of the programme implementation, the following formats were used:

a) clinical conferences in English;

b) master-classes on the organisation of a scientific training conference in English for postgraduate students;

c) master-classes on the organisation of a student report contest in English;

d) master-classes on teaching academic writing;

e) round-table discussions and scientific-research sessions on the most relevant problems in teaching foreign languages for medical students (the role of humanities in medical training and the problem of humanism in a medical profession; holding internet-based foreign language competitions, etc.).

\section{RESULTS}

Advocating a novel type of advanced training ESP programme for language teachers in higher education, we determined a number of principles that should guide the implementation of effective advanced training programmes in the modern educational context. Essential among these is 'The Principle of Teachers' Autonomy Stimulation'. This includes stimulation of the teachers' autonomy in their professional activity and lifelong personal and professional development based on constant reevaluation of their own experience [19]. Following this principle, within the implementation of advanced training programmes, particular emphasis should be put on involvement of teachers into the process of course organisation, their active participation in making sense of a new practice using their own metacognitive skills to create their multi-dimensional awareness of the educational context. Specifically, it is important to provide the teachers with opportunity to select what they would like to learn to make the course grounded in a particular teachers' practice. 
Of extreme importance is 'The Principle of Professionalisation' of the teachers' advanced training, ensuring that teachers are familiar with the new ways of professionally-oriented language training organisation. Following this principle, within the implementation of advanced training programmes, particular emphasis should be put on profession, interdisciplinarity, and on student teachers' ability to apply new knowledge to their actual contexts of teaching. 'The Principle of Problematisation' of the teachers' advanced training requires relevant programme content, reflecting actual challenges faced by teachers in their professional activity. 'The Principle of Innovative Orientation of the teachers' advanced training is also extremely important since it ensures both qualitative innovational self-development of teachers and their creativity. Supporting the principles mentioned above, 'The Principle of Internationalisation of the Teachers' advanced training requires that the course is relevant to the modern international tendencies in both language training methodology and healthcare practice development. This principle also ensures that teachers are provided with opportunities to use a foreign language in real intercultural communication.

The complex of these principles aims at making the process of advanced training experiential and collaborative through involving critical review of teachers' personal experience as well as multi-dimensional evaluation (evaluation by international experts, selfevaluation, peer-evaluation, and learner-evaluation practices). Based on the above mentioned principles of organisation of advanced training programmes and following the Bayar's components of effective professional development activities in terms of teachers' perspective (Bayar, 2014), we designed an advanced training ESP programme for language teachers. The special features of the course are:

a) expert coaching on the use of Medical English in clinical practice;

b) engagement of clinicians, postgraduate and undergraduate medical students;

c) emphasis on scientific activity (academic writing);

d) discussions on urgent foreign language teaching-related psychological and pedagogical issues (ways to develop teachers' and learners' motivation and autonomy (Gavrilyuk, 2017), to overcome burnout in teachers, to use the 'Foreign language' enriching potential) to foster foreign language teachers' multi-dimensional awareness and individual reflection;

e) collaborative and cooperative learning involving the exchange of ideas and innovative experience in teaching Medical English (development of new manuals, implementation of new technologies, etc.), peer observation and peer review within the study groups to promote self-evaluation and peer-evaluation;

f) informal increase in the programme content through reflection-stimulating preparation of course reports and the development of a special practice-oriented e-learning environment for teachers of Medical English on the website of EMC.

The advanced training programme included interactive lectures, a set of round tables discussions, panels and tutorials covering the issues of the creation and development of English speaking environment in a modern medical university and of foreign language training effectiveness improvement. A practical part of the programme included masterclasses and conferences with the participation of foreign and local clinicians, postgraduate and undergraduate medical students and residents of KrasSMU.

The format of a clinical conference in English proved to be one of the most effective ones. However, it required a large amount of preparatory work with the participants: clinicians, postgraduate students, interns and residents from the KrasSMU departments of 
oncology, pathological physiology, neurology and medical genetics. The participants worked under the guidance of an interdisciplinary team made up of Russian specialists from clinical departments and the department of Latin and Foreign languages, and foreign specialists in the area of medicine and Medical English.

\section{DISCUSSION AND CONCLUSIONS}

Meeting the new demands of the modern medical setting means that medical universities should not only change their approach to developing the English language skills of students, but also to the development of English language teachers. The better prepared and updated the teachers are, the greater the academic achievement of the students. That is why implementing relevant professional development programmes enhancing English language teachers' quality seems to be critical to upgrading the medical universities capacity to influence positive students' development in the context of medical internationalisation and the growing cultural and linguistic diversity.

This paper describes a new type of international advanced training programme for teachers of Medical English by defining some fundamental principles that guide an effective professional development programme. By moving beyond the limits of the 'foreign language' discipline towards a broader context of professional activity of modern clinicians, this model considers some foreign language teaching implications within the framework of interdisciplinary teaching practices (Khatib et al., 2013; Wermke \& Höstfält, 2014; Zhang \& Atkin, 2010) and the idea of effective professional self-development (Garanina et al., 2017; Tomassini \& Zanazzi, 2014).

The described characteristics of the course constitute a new approach to the organisation of advanced training programmes. As the results of the course implementation have shown, this new approach appears more effective in comparison with the traditional one. The teacher participants of the programme noted that the new format of advanced training required their active engagement and highly creative activity. At the same time, it enabled the teachers to become real co-authors of the programme, stimulating teachers' autonomy and establishing the foundations for their independent professional self-development.

The results of the described approach to advanced training course organisation show evidence of the programme's effectiveness, not only with the foreign language teachers but also to all the participants of events within the framework of the programme (students, residents, clinicians, university staff), who had the opportunity to participate in the real training to develop their speaking and intercultural communication skills. The summative evaluation of the course results suggests that this kind of advanced training for teachers needs to be implemented in other medical and pharmaceutical universities of Russia. To a great extent, the success of this kind of programme also depends on the participation of foreign specialists to ensure real intercultural communication. Moreover, it is difficult to overestimate the value of international clinical study sessions, conducted in the clinical environment (not in a classroom), that provide interdisciplinarity through the participation of both language teachers and foreign clinicians. This training format was seen as beneficial not only by its participants - foreign language teachers, but also by the foreign specialists who emphasised the great value of intercultural communication with the different players of the educational setting of medical universities (McFarland \& Markovina, 2016). 
Therefore, we demonstrate the benefits of organising an international advanced training course for Medical English teachers. As our findings suggest, first, the developed course is more responsive to the changes taking place in the international medical community. Second, it ensures the development of foreign language teachers' autonomy, pedagogical research and practice-based implementation of new educational technology (Forzani, 2014) all leading to enhancing teachers' professional self-development, performance and job satisfaction. Third, it contributes to the internationalization and professionalization of medical education. The results of the study dictate the need for a broader research, which would reveal other practical opportunities for this model implementation in the modern Russian higher education.

\section{REFERENCES}

Amano, T. et al. (2016). Languages are still a major barrier to global science. PLoS Biol, 14, 12: e2000933. Retrieved April 202019 from http://dx.doi.org/10.1371/journal.pbio. 2000933

Bayar, A. (2014). The Components of effective professional development activities in terms of teachers' perspective. International Online Journal of Educational Sciences, 6 (2). 319 327. Retrieved January 102019 from http://dx.doi.org/10.15345/iojes.2014.02.006

Compton, L.K.L. (2015). Preparing language teachers to teach language online: a look at skills, roles, and responsibilities, Computer Assisted Language Learning, 22(1), 73-99. Retrieved April 202019 from http://dx.doi.org/10.1080/09588220802613831

Darling-Hammond, L. (2000). Teacher quality and student achievement: a review of state policy evidence. Education policy Analysis Archives, 8(1). Retrieved April 142018 from http://epaa.asu.edu/epaa/v8n1

Epelboin, Y. (2015). MOOCs and pedagogy: where are we heading? EUNIS Journal of Higher Education IT, 3. Retrieved April 272019 from http://www.eunis.org/erai/2015-3/

Fan, X., \& Wu, G. (2011). Foreign language teachers' professional development in information age. In: Chen R, ed. International Conference, ICICIS Chongqing, China, Jan 8-9, 2011. Proceedings, Part II: 233-237. Retrieved April 262019 from http://dx.doi.org/ 10.1007/978-3-642-18134-4_37

Forzani, F. (2014). Understanding "core practices" and "practice-based" teacher education: Learning from the past. Journal of Teacher Education, 65 (4), 357-368. Retrieved January 262019 from http://dx.doi.org/10.1177/0022487114533800

Frizen, M.A. (2016). Subjectivity of the formed personality in respect of self-development. Vestnik Kemerovskogo gosudarstvennogo universiteta [Newsletter of the Kemerovo State University], 2, 136-139. Retrieved January 202019 from http://dx.doi.org/10.1234/ XXXX-XXXX-2016-2-136-139 (in Russian).

Garanina, Zh.G. et al. (2017). The structural model of future employees personal and professional self-development. Integratsiya obrazovaniya [Integration of Education], 21 (4), 596-608. Retrieved January 202019 from http://dx.doi.org/10.15507/1991-9468.089. 021.201704.596-608 (in Russian).

Gavrilyuk, O. A. et al. (2017). Organisation of the system of personal and professional development for medical academic staff: the problem and its solutions. Vestnik Novosibirskogo gosudarstvennogo pedagogicheskogo universiteta [Novosibirsk State Pedagogical University Bulletin], 7(3), 19-36. Retrieved April 202019 from http://dx.doi.org/10.15293/2226-3365.1703.02 (in Russian). 
Gavrilyuk, O.A. (2015). Autonomy as a core value of lifelong learning. Zhurnal SFU. Gumanitarnye nauki [Journal of Siberian Federal University. Humanities \& Social Sciences]. 8 (11), 2283-2290. Retrieved April 272019 from http://elib.sfu-kras.ru/ bitstream/handle/ 2311/19879/14Gavrilyuk. pdf?sequence $=3$

Jiménez, R.M. (2007). Developing Professional Autonomy: A Balance Between License and Responsibility. Independence, 40 (IATEFL Learner Autonomy SIG) Spring, 32-33. Retrieved April 272019 from https://www.researchgate.net/publication/319217028_ Developing_professional_autonomy_A_balance_between_license_and_responsibility/link 1599c5f88a6fdcc50034c7dd9/download

Kennedy, M. M. (2016). How does professional development improve teaching? Review of Educational Research, 2016, 86 (4), 945-980. Retrieved May, 03, 2019 from http://dx.doi.org/10.3102/0034654315626800

Khatib, M., et al. (2013). Humanistic Education: Concerns, Implications and Applications. Journal of Language Teaching and Research, 4 (1), 45-51 Retrieved April 232019 from http://dx.doi.org/10.4304/jttr.4.1.45-51

Kyndt, E. et al. (2016). Teachers' everyday professional development. Review of Educational Research, 86(4), 1111-1150. Retrieved May, 02, 2019 from http://dx.doi.org/10.3102/ 0034654315627864

Mann, S. Language teacher's development. Lang Teach, 2005, no. 38, pp. 103-118. Retrieved January 202019 from http://dx.doi.org/10.1017/S0261444805002867

Markovina, I. Yu. et al. (2017). International advanced training programme for medical university teachers of English: a new model. Meditsinskoe obrazovanie i vuzovskaya nauka [Medical Education and University Science], 1(9), 61-64. (in Russian).

Markovina, I.Yu. et al. (2013). Organizatsiya obucheniya inostrannomu yazyku v meditsinskom vuze $\mathrm{v}$ usloviyakh FGOS [Teaching foreign languages in medical universities in the context of the Federal State Educational Standards]. Vestnik MGLU [Newsletter of the Moscow State Linguistic University], 12(672), 41-48. (In Russian)

McFarland, J. \& Markovina, I. (2016). International Clinical Sessions - A New Way to Teach Professional Communication Cross-Culturally. In: Pop A, Naznean A (eds). Trends in Medical Language Teaching and Learning. Tirgu-Mures: University Press, 121-126.

Noorda, S. (2014). Human capital, the oft-forgotten key challenge for universities. In: L. Weber, J. Duderstadt, ed. Preparing Universities for an Era of Change. London, Economica Publ. pp. 187-197. Retrieved April 202019 from https://catalog.hathitrust. org/Record/101708468

Opfer, D. \& Pedder, D. (2011). Conceptualizing teacher professional learning. Review of Educational Research. 81, 376-407. Retrieved April 21, 2019 from http://dx.doi.org/ $10.3102 / 0034654311413609$

Ozdemir, E.A. \& Dikilitaş, K. (2016). Teachers' professional development in the digitized world: a Sample blended learning environment for educational technology training. In: Educational Leadership and Administration: Concepts, Methodologies, Tools, and Applications. Hershey, PA: IGI Global, 681-691. http://dx.doi.org/10.4018/978-1-52251624-8.ch033

Pavel, E. (2014). Teaching English for Medical Purposes. Bulletin of the Transilvania University of Braşov Series VII: Social Sciences. Law, 7 (56), 2, 39-46.

Raths, J. \& Lyman, F. (2003). Summative evaluation of student teachers: an enduring problem. Journal of Teacher Education, 54(3), 206-216. 
Shawer, S.F. \& Alkahtani, S.A. (2013). Career development in language education programs. Australian Journal of Teacher Education, 38 (6), 13-32. Retrieved January 252019 from http://dx.doi.org/10.14221/ajte.2013v38n6.8

Svensson, L. \& Wihlborg, M. (2010). Internationalising the content of higher education: the need for a curriculum perspective. Higher Education, 60(6), 595-613. Retrieved April 26 2019 from http://dx.doi.org/10.1007/s10734-010-9318-6

Toköz Göktepe, F. (2015). A critical analysis of foreign language teacher education practices in Turkey. International Journal of Languages' Education and Teaching, 3, (1), 128-143.

Tomassini, M. \& Zanazzi, S. (2014). Reflexivity and self-development of competencies as key drivers in individuals' learning and career paths: cases from Italy. Research in Comparative and International Education, 9(3), 301-312. Retrieved January 142019 from http://dx.doi.org/10.2304/rcie.2014.9.3.30

Trust, T. et al. (2016). "Together we are better": Professional learning networks for teachers. Computers \& Education, 102, 15-34. Retrieved April 202019 from http://dx.doi.org/ 10.1016/j.compedu.2016.06.007

Van Driel, J.H. et al. (2012). Current trends and missing links in studies on teacher professional development in science education: a review of design features and quality of research. Studies in Science Education, 48 (2), 129-160. Retrieved April 202019 from http://dx.doi.org/10.1080/03057267.2012.738020

Wermke, W. \& Höstfält, G. (2014). Contextualizing Teacher Autonomy in Time and Space: A Model for Comparing Various Forms of Governing the Teaching Profession. Journal of Curriculum Studies, 46 (1), 58-80. Retrieved January 202019 from http://dx.doi.org/ 10.1080/00220272.2013.812681

Yang, M. S. et al. (2016). Factors related to technological pedagogical content knowledge (TPACK) of college instructors: Focusing on the epistemological beliefs and the social support. Journal of Digital Convergence, 14(11), 1-12. Retrieved January 252019 from http://dx.doi.org/10.14400/JDC.2016.14.11.1

Zhang, L. \& Atkin, C. (2010). Conceptualizing humanistic competence in the language classroom by TJP - A Chinese case. International Education Studies, 3(4), 121-127. Retrieved January 202019 from http://dx.doi.org/10.1177/088840649401700203 